\title{
Architecture_MPS
}

\section{Dilapidated Dwelling}

Patrick Keiller ${ }^{1}$

How to cite: Keiller, P. 'Dilapidated Dwelling.' Architecture_MPS, 2015, 6(1): 3, pp. 1. DOI: https://doi.org/10.14324/111.444.amps.2015v6i3.001.

Published: 01 January 2015

\section{Peer Review:}

This article has been peer reviewed through the journal's standard Editorial double blind peer review.

\section{Copyright:}

(C) 2015, The Author(s). This is an Open Access article distributed under the terms of the Creative Commons Attribution License (CC-BY) 3.0 https://creativecommons.org/licenses/by/3.0/, which permits re-use, distribution and reproduction in any medium, provided the original author and source are credited • DOI: https://doi.org/10.14324/111.444.amps.2015v6i3.001

\section{Open Access:}

Architecture_MPS is a peer-reviewed open access journal. 


\title{
Title: Dilapidated Dwelling
}

\section{Author: Patrick Keiller}

Architecture_media_politics_society. vol.6, no.3

January 2015

\begin{abstract}
:
Where I live, there seem to be two kinds of space. There is new space, in which none of the buildings are more than about ten years old, and there is old space, in which most of the buildings are at least twenty years old, a lot of them over ninety years old, and all are more or less dilapidated.
\end{abstract}

Patrick Keiller begins his 1998 essay The Dilapidated Dwelling with a concise and simple description of the issues he raises in both the essay and the film to which it relates, The Dilapidated Dwelling, 2000. In both film and word Keiller's description of the UK's physical infrastructure at the turn of the millennium was both depressingly evident and in need of explanation. Continuing in the vein of his most famed films London, 1994, and Robinson in Space, 1997, The Dilapidated Dwelling is narrated by an invisible voice that probes the peculiarities of the economic, political and social conditions of late 20th century Britain through the prism of its infrastructure, urban blight and, in particular, its housing.

The narrator, a woman is recalled to Britain after two decades in the Arctic investigates 'the predicament of the house', discovering that the most recent advances in industrial manufacture have left the house building industry practically untouched. By contrast, changes to the global economy and the emergence of the digital age have conspired to create wealth that has seen the market price of the existing, dilapidated housing stock skyrocket. Revisiting the ideas of Constant, Buckminster Fuller and Archigram she discusses the anomalies of housing supply and demand that have allowed some to escape housing poverty and yet leave millions in 'dilapidated dwellings'.

To coincide with the the launch of its three year project Housing - Critical Futures, Architecture, Media, Politics, Society, is republishing Keiller's essay and re-showing his film. The essay is reprinted from Keiller's recent book, The View From the Train, Vesro, 2013; and the film is shown as part of a one day series of film screenings and debates about the effects of housing on issues of public health, Housing, Health and Film. Screened at the Bluecoat Chambers Art Gallery, Liverpool, the film is accompanied by debates from architects, filmmakers and public health officials. 


\section{Title: Dilapidated Dwelling}

\section{Author: Patrick Keiller}

\section{Architecture_media_politics_society. vol.6, no.3.}

January 2015

The full text of the Dilapidated Dwelling article is available in: Keiller, Patrick. 2013. The view from the train: cities and other landscapes. London: Verso, 2013.

This article was published by Architecture_MPS to coincide with the screening of Patrick Keiller's film of the same name. The screening formed part of a one day event entitled Housing, Health and Film held at the Bluecoat chambers Art Gallery, Liverpool, $10^{\text {th }}$ January 2015. In its turn, this event formed part of a 3 year long project led by Architecture_MPS on the issue of affordable housing, entitled Housing Critical Futures.

\section{Housing - Critical Futures}

Housing - Critical Futures is an international architectural, social and art forum for 2015-17, inclusive. It is a three year programme of events and projects taking place in various international venues. It involves a series of academic conferences; an international student design competition; a number of Housing; a series of film / media / art events; workshops and a web platform for the sharing of project information.

Details: http://architecturemps.com/housing-critical-futures/ 